\title{
Evaluation Of Indonesia's National Energy Policy: A Regional Dilemma In Indonesia Through Simulation Approach
}

\author{
Adrianus Amheka ${ }^{1 *}$, Julius A. Tanesab ${ }^{1}$, Philipp R. Thies ${ }^{2}$, Kathleen Aviso ${ }^{3}$ \\ \{adrianus.amheka@gmail.com, julius_halan@yahoo.co.id, p.r.thies@exeter.ac.uk, \\ kathleen.aviso@dlsu.edu.ph\} \\ State Polytechnic of Kupang, Indonesia ${ }^{1}$, \\ University of Exeter, United Kingdom (Great Britain) ${ }^{2}$ \\ De La Salle University, Philippines ${ }^{3}$
}

\begin{abstract}
The target of Indonesia's national primary energy supply in 2025 and 2050 are estimated to be at least 400 MTOE and 1000 MTOE accumulated from a total of 34 Provinces in Indonesia to fill the target. At the same years, target for per capita primary energy utilization of $1.4 \mathrm{TOE}$ and 3.2 TOE and per capita electricity utilization of at least $2,500 \mathrm{kWh}$ and $7,000 \mathrm{kWh}$. This study aims to determine the magnitude of the achievement targets of national energy policies from several provinces in Indonesia by taking samples, namely the Nusa Tenggara Timur, West Java, and Central Java Provinces. The quantitative approach for the year 2010 to 2015 data periods of the NTT Province have taken by considering parameters, among others the economic structure, environmental conditions, and specific energy conditions. All data are processed through LEAP assistance. The study results have shown a dilemma in achieving national energy policy targets represented by three sample provinces.
\end{abstract}

Keywords: Energy security, Nusa Tenggara Timur, Central Java, West Java.

\section{Introduction}

There are still one fifth of the population of the earth who do not have electricity in their living needs [1] this matter is of concern to the world government through United Nation efforts to achieve sustainable development goals (SDGs) in the energy sector. Various efforts at the global level continue to be made in meeting the demand and supply of energy in achieving national energy security each country through [2]-[4] china, Indonesia, Pakistan, Vietnam [5][8]. The new paradigm of the Indonesian government relating to the supply and demand of national energy, namely energy as development capital has emphasized the use of renewable energy (RE) as optimal as possible for the welfare of society. To achieve the government's target through the Indonesia National Energy Policy (INEP) of 2014 which targeted the supply of primary energy in 2025 to at least 400 MTOE and $23 \%$ of the total energy mix comes from RE and in 2050 the primary energy supply is at least 1000 MTOE with the energy mix contributing from the RE at least 31\% [9]-[11]. Detail of INEP as shown in Table 1. 
Table 1. Indonesia National Energy Policy (INEP) targets

\begin{tabular}{|c|c|c|c|c|c|c|}
\hline No & INEP Targets & Units & 2015 & 2020 & 2025 & 2050 \\
\hline 1 & Primary energy supply & Juta TOE & - & - & $>400$ & $>1.000$ \\
\hline \multirow[t]{5}{*}{2} & Energy Mix target & & & & & \\
\hline & a. Renewable Energy & $\%$ & - & - & $>23$ & $>31$ \\
\hline & b. Crude oil & $\%$ & & & $<25$ & $<20$ \\
\hline & c. Coal & $\%$ & - & - & $>30$ & $>25$ \\
\hline & d. Natural gas & $\%$ & - & - & $>22$ & $>24$ \\
\hline 3 & Provision of electricity generation & GW & & & $>115$ & $>430$ \\
\hline 4 & Electrification ratio & $\%$ & 85 & 100 & 100 & 100 \\
\hline 5 & Utilization of primary energy per capita & TOE & - & - & 1,4 & 3,2 \\
\hline 6 & Utilization of electricity per capita & $\mathrm{kWh}$ & & & 2.500 & 7.000 \\
\hline 7 & Energy elasticity & & - & - & & \\
\hline 8 & Decrease in energy intensity & $\%$ & \multicolumn{4}{|c|}{$1 \%$ per year } \\
\hline 9 & Household gas usage ratio & $\%$ & 85 & & & \\
\hline
\end{tabular}

Government efforts by involving various stakeholders, especially at the regional level in country continue to be carried out as the most effective step in achieving national energy independence [12]-[17] through promote maximize uses of RE and become an important role in carrying out energy policy transformation because of the added value strategy of the environmental and economic aspects [13], [18]-[21] However, the current policy of implementing regional energy that provides added value is shown un optimal results because energy use in carrying out development activities still dominate on a fossil basis. Evaluations in recent years show that the primary energy mix for RE has only reached $6.61 \%$ in 2016 . This achievement is still far from what was expected in reaching $23 \%$ in 2025.

One obstacle faced is the lack of inventory of data collection of national energy mix distributed at the regional level in all provinces in Indonesia. At present there are only 6 provinces over a total of 34 provinces in Indonesia that already have a regional energy plan, among other are East Java, Central Java, and Nusa Tenggara Timur provinces which contain general quantitative data regarding the achievement of national energy policy targets contributed at the regional level [22]-[24].

\section{Material and Methods}

The use of energy in economic activities becomes very important because development cannot run optimally without sufficient energy supply to meet the energy needs of an area. National government targets in meeting the demand for primary energy per capita in 2025 and 2050 are $1.4 \mathrm{TOE}$ and 3.2 TOE respectively, while to meet the per capita electrical energy needs 
is targeted to reach $2,500 \mathrm{kWh}$ and $7,000 \mathrm{kWh}$ in the same year. It is expected that each province makes an energy plan using the same model structure as the national level with some adjustments according to the value of social, economic, environmental indicators and the availability of primary energy resources of RE. Central Java province, until 2016 still relied heavily on fossil energy as the main energy source used, which is the energy mix that comes from fossils in the form: coal and oil to reach $36.32 \%$ and $41.94 \%$ respectively and the rest are from gases and RE. Fossil energy sources are still widely used by the community of Central Java, to meet the needs in the transportation sector, electricity generation, and industry.[24]

\subsection{Central Java Energy Plan}

In Central Java in 2016, fossil energy is still a mainstay as seen in the primary energy mix still dominates by coal, oil and natural gas to meet the needs in the transportation, electricity generation and industrial sectors. The use of conventional technology became one of the obstacles in utilizing RE in addition to basic infrastructure as a bridge, the use of RE is constrained by the topographical conditions of the Province so that electricity distribution is uneven. Economic prices commodity energy sources also become one of the obstacles in implementing RE due to subsidy and RE prices are not yet stable due to overlapping rules. On the other hand, the primary energy potential of the Province is quite abundant such as solar, water, geothermal, bioethanol, biofuels, biomass, biogas, and swamp gas. For solar energy potential, Central Java Province has solar radiation of $3.5 \mathrm{kWh} / \mathrm{m} 2 /$ day up to $4.67 \mathrm{kWh} / \mathrm{m} 2 /$ day. At present, there are 5,247 units of solar home system with a capacity of $262.35 \mathrm{kWp}$. There are 14 communal solar power with a total capacity of $190.5 \mathrm{kVA}$. Public street lighting from small solar power has installed of 737 units with a capacity of $198.99 \mathrm{kWp}$. For hydropower, according to the Electricity Supply Business Plan, the potential primary energy available will be able to support the installed capacity of up to $350 \mathrm{MW}$, while for geothermal potential it is estimated can be developed to reach 1,981 MW spread over 14 strategy locations. For bioethanol and biofuel can be developed reach to 644,386 Litters. Potential use of waste as a RE source to solve solid waste problems [25] are 106,972.75 MWe. For wind power, the potential wind speed reach $4.23 \mathrm{~m} / \mathrm{s}$ to $2.69 \mathrm{~m} / \mathrm{s}$. In 2016, electricity consumption in Central Java province is around $21,675 \mathrm{GWh}$ and its electrification ratio is $93.51 \%$.

Projected energy demand still dominated by the transportation sector reach to $66,079,964$ BOE in 2025 dan increased to 468,598,670 in 2050 followed by Industry and household sectors, while estimated energy use per type is still dominated by fuel oil (premium), namely in 2025 reaches to 42,787 Thousand BOE and 306,505 Thousand BOE in 2050 and followed by coal which rose rapidly after 2035, but the demand for electricity from 2016 to 2050 was a steady increase in percentage terms.

\subsection{West Java Energy Plan}

Up to 2015 the final energy consumption in West Java province reached 19.19 MTOE, with a mixture of Oil 35\%, natural gas $36 \%$, Coal $23 \%$, and ET only $6 \%$. However, the share of $\mathrm{RE}$ in electricity generation is quite high at $34 \%$. Various strategic policies have been carried out in order to boost the use of RE in this province, starting from the inventory of potential ET data to the mastery of exploration technology and revitalization of the energy sector licensing process, especially with regard to the ET and the handling of land and spatial issues. The potential for RE in West Java reaches 29,764MW and has been installed at 3,283 MW or only $11.03 \%$ of the total potentials of geothermal, water, solar, wind, bioenergy, and marine energy. As for all these potentials, the biggest is Bioenergy at 2,554 MW. In achieving the national energy policy target, the Provincial Government of West Java has predicted the final energy 
needs to reach 34.29 MTOE in 2025. The sector that consumes the most energy is industry at $42.95 \%$ and followed by the transportation and household sectors respectively at $35.81 \%$ and $17.83 \%$. While the primary energy mix in the same year is $20.1 \%$ for ET; $27.66 \%$ for oil; $27.71 \%$ for natural gas and coal $24.53 \%$. In addition, encouragement to various stakeholders to participate in realizing the achievement of per capita electrical energy utilization in 2025 around $1,693 \mathrm{kWh}$ and $4,768 \mathrm{kWh}$ in 2050 . Strategic efforts continue to be carried out in order to realize the vision of energy security that is equitable, sustainable and environmentally sound with prioritizing to the RE and energy conservation in West Java Province.

\subsection{Methods}

This study aims to determine the magnitude of the achievement targets of national energy policies from several provinces in Indonesia by taking samples, namely Nusa Tenggara Timur, West Java, and Central Java provinces. For the energy profile data, the provinces of West Java and Central Java were obtained using a macro energy data inventory approach in general due to the limited availability of data. Accuracy of data is obtained through questionnaires and other general scientific references in addition to the official regional energy profiles of the two provinces that have been legalized. The quantitative approach for the year 2010 to 2015 data periods of the Nusa Tenggara Timur province have taken by considering parameters, among others the economic structure, environmental conditions, and specific energy conditions. For economic data are the basic macroeconomic assumptions and related demographic data. While energy data are specific on the primary energy potential of RE and for environmental indicators are the amount of greenhouse gases (GHG) emissions were taken from Provincial GHG Regional Action Plan data. In detail, the construction of the model is made according to Figure 1.

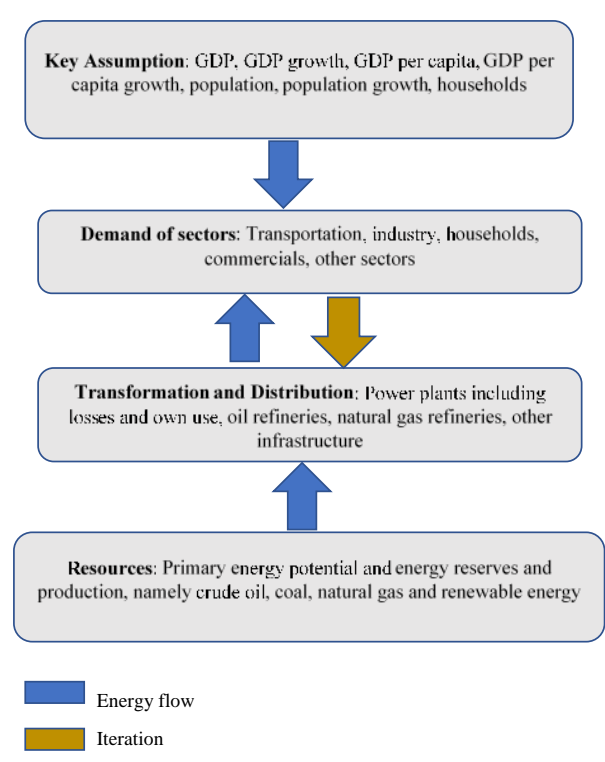

Fig. 1. Model construction of Nusa Tenggara Timur Provincial energy profile

For energy transformation, specifically for the Nusa Tenggara Timur province does not include oil refineries and natural gas refineries in the modelling, because the potential for these 
resources is not found in this province. It is also applied for primary energy sources for crude oil and coal that are not available in this Province so that the construction characteristics of the Nusa Tenggara Timur provincial model differ from the national and other provincial levels in terms of the availability of potential primary energy sources other than RE. In the order of primary energy supply, it is also integrated with various applicable approaches related to longterm energy mix policies, economies of scale through the intervention of RE-based energy policies, geographical conditions of the Nusa Tenggara Timur province, and technologies that have been and will be applied short and long term. As for iteration model of level of transformation and distribution using mathematical equations through software Long-range Energy Alternative Planning (LEAP) system according to the national level model with adjustments to fossil energy resource variables [26]-[28].

\section{Results and Discussion}

As result, the Nusa Tenggara Timur province's primary energy supply in 2025 is 2.97 Million TOE or $0.74 \%$ of the total national needs in INEP, s whereas in 2050 only $0.76 \%$ of the total predictions of INEP. The details as shown in Figure 2.

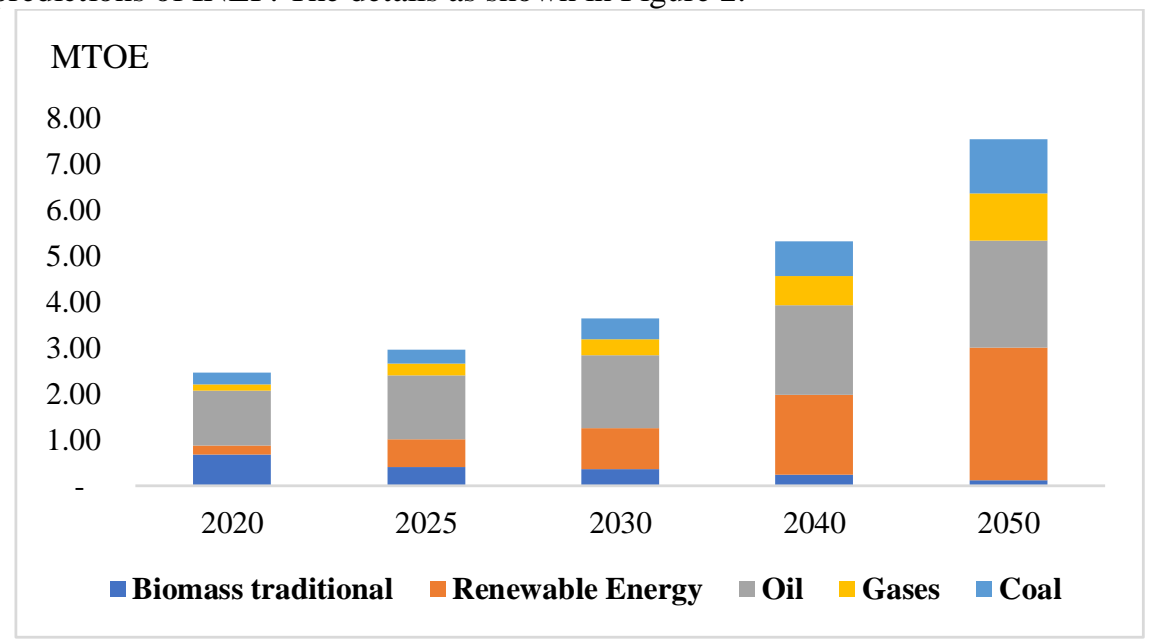

Fig. 2. Provision of primary energy in NTT Province 2025 - 2050

If the total is accumulated with two major provinces namely Central Java and West Java, each of which provides primary energy in 2025 and 2050, for Central Java of 18.20 MTOE or $4.55 \%$ and 110.36 MTOE or equivalent to $11.04 \%$ of the total accumulated national supply, respectively. Whereas for West Java the supply of primary energy in 2025 and 2050 was 51.98 MTOE or equivalent to $13 \%$ and 137.55 MTOE or equivalent to $13.76 \%$ of the total accumulated national supply, respectively. The total accumulation of the three provinces in supporting INEP was only able to reach 131.53 MTOE or equivalent to $33 \%$ of the INEP target in 2025 and 255.46 MTOE or equivalent to $26 \%$ of the INEP target in 2050. Whereas the gap between primary energy consumption per capita and the INEP target is quite large as shown in Table 1. 
Table 1. Primary energy consumption per capita

\begin{tabular}{|c|c|c|}
\hline & \multicolumn{2}{|c|}{ Units: TOE } \\
\hline Provinces & 2025 & 2050 \\
\hline Nusa Tenggara Timur & 0.43 & 1.02 \\
\hline West Java & 0.97 & 2.15 \\
\hline Central Java & 0 & 0 \\
\hline INEP Target & 1.4 & 3.2 \\
\hline
\end{tabular}

NTT province is only able to contribute per capita primary energy consumption to only 0.43 TOE in 2025 and 1.02 TOE in 2050, and West Java at 0.97 TOE and 2.15 TOE in the same year target, whereas Central Java still has not provided a target. The three provinces show that the INEP target of 2025 in primary energy consumption of 1.4 TOE and 3.2 TOE in 2050 is not achieved, this also provides a dilemma for the government in achieving the INEP target for the past five years since it was legalized. This dilemma is also likely to affect the cumulative value of other 34 provinces in providing primary energy supply due to limited coordination in fulfilling energy profile data, in addition to limited human and technological resources in identifying, exploring and utilizing natural energy resources. Another thing is the utilization of electricity per capita, where the comparison between NTT and INEP provincial levels is shown in Table 2.

Table 2. Per capita Electricity Needs

\begin{tabular}{lcccc}
\hline & \multicolumn{2}{c}{$\mathbf{2 0 2 5}$} & \multicolumn{2}{c}{$\mathbf{2 0 5 0}$} \\
\cline { 2 - 5 } & NTT Province & INEP & NTT Province & INEP \\
\hline Per capita Electricity Needs (kWh) & 1500 & 2,500 & 2,149 & 7,000 \\
Comparison of NTT Provinces Per & $25.35 \%$ & & $30.71 \%$ & \\
Capita Electricity Needs and INEP & & & & \\
\hline
\end{tabular}

The simulation results of Nusa Tenggara Timur province per capita electricity need in 2025 are only $1,500 \mathrm{kWh}$ and 2,149 $\mathrm{kWh}$ in 2050 which far from INEP target namely 2,500 kWh and $7,000 \mathrm{kWh}$ or gap of $25.35 \%$ and $30.71 \%$. As for the provinces of Central Java and West Java, they have not provided targets from various references in the official documents available, with reference to the electricity needs of the Nusa Tenggara Timur province, it is very likely that the INEP target in electricity consumption per capita unable to achieve optimally. Therefore, innovative policies in the form of priorities for energy development are needed, accelerating the use of energy resources that are prioritized for environmentally friendly energy, infrastructure and access for the community to energy and the energy industry need to be improved, in addition to institutional development and funding that targeted in accordance with the government's fiscal conditions and also continue to make concrete efforts in order to improve national energy independence and security. In general, the comparative results of the three example provinces for Indonesia, in fact still provide the potential for inadequacy in the INEP target which is likely to be caused by a number of specific problems, namely dependence on fossil energy is still very high, access and infrastructure of energy is limited, management of RE potential has not been optimal, limited resources for research and innovation in the field of energy management and development, there are no regulations regarding energy management in the regions and the use 
of energy has not yet addressed the issue of environmental sustainability and its impact on global climate change.

\section{Conclusion}

The increasingly important role of the energy sector in Indonesia's development so that it requires the planning of good energy resource management by leading to policies to realize energy security in order to support sustainable development. A complete general profile describing the provincial government's policy on regional energy management plans is urgently needed to analyse the energy policy portrait in developing national energy policy scenarios and strategies while preparing the foundation for sustainable national development that in line with sustainable development goals. Integration of energy systems and the environment needs to get an important portion in long-term energy management so it can create sustainable consumption patterns while being able to control the increase in environmental loads in the form of GHG emissions. Innovative studies and implementation need continue to be carried out by involving various aspects and stakeholders that are burden on national energy consumption. Studies related to carbon taxes [29], electricity prices, and its impacts on the implementation of the regional-level green economy are indispensable [30].

\section{References}

[1] E. Panos, M. Densing, and K. Volkart, “Access to electricity in the World Energy Council's global energy scenarios: An outlook for developing regions until 2030," Energy Strateg. Rev., vol. 9, pp. 28 49, 2016.

[2] R. FUJIKURA and H. IMURA, "Symposium: A Long-Term Perspective on Environment and Development in the Asia-Pacific Region," Stud. Reg. Sci., vol. 26, no. 1, pp. 305-308, Dec. 1995.

[3] D. Von Hippel, T. Suzuki, J. H. Williams, T. Savage, and P. Hayes, "Energy security and sustainability in Northeast Asia," Energy Policy, vol. 39, no. 11, pp. 6719-6730, Nov. 2011.

[4] K. B. Debnath and M. Mourshed, "Forecasting methods in energy planning models," Renew. Sustain. Energy Rev., vol. 88, pp. 297-325, May 2018.

[5] Y. Deng, L. Xu, Y. Yuan, and K. Mancl, "Review of Energy Finance and Corresponding Policies in Promoting Renewable Energy Sustainable Development in China," 2020, pp. 279-292.

[6] M. Kamran, M. R. Fazal, and M. Mudassar, "Towards empowerment of the renewable energy sector in Pakistan for sustainable energy evolution: SWOT analysis," Renew. Energy, vol. 146, pp. 543-558, Feb. 2020.

[7] H. T. Nguyen, K. B. Aviso, D. Q. Le, N. Kojima, and A. Tokai, "A linear programming inputoutput model for mapping low-carbon scenarios for Vietnam in 2030," Sustain. Prod. Consum., vol. 16, pp. 134-140, 2018.

[8] M. M. Rafique and S. Rehman, "National energy scenario of Pakistan - Current status, future alternatives, and institutional infrastructure: An overview," Renewable and Sustainable Energy Reviews, vol. 69. Pergamon, pp. 156-167, 01-Mar-2017.

[9] P. Regulation, National Energy General Plan. Indonesia, 2017.

[10] Ministry of Energy and Mineral Resources, Indonesia National Energy Policy (INEP). Indonesia: Ministry of Energy and Mineral Resources, 2014.

[11] S. Mujiyanto and G. Tiess, "Secure energy supply in 2025: Indonesia's need for an energy policy strategy,” Energy Policy, vol. 61, pp. 31-41, Oct. 2013. 
[12] V. Vivoda, "Evaluating energy security in the Asia-Pacific region: A novel methodological approach," Energy Policy, vol. 38, no. 9, pp. 5258-5263, 2010.

[13] Y. Nan, X. Fan, Y. Bian, H. Cai, and Q. Li, "Impacts of the natural gas infrastructure and consumption on fine particulate matter concentration in China's prefectural cities: A new perspective from spatial dynamic panel models," J. Clean. Prod., vol. 239, p. 117987, Dec. 2019.

[14] I. García Kerdan, F. Jalil-Vega, J. Toole, S. Gulati, S. Giarola, and A. Hawkes, "Modelling costeffective pathways for natural gas infrastructure: A southern Brazil case study," Appl. Energy, vol. 255, p. 113799, Dec. 2019.

[15] M. Song, S. Zhu, J. Wang, and J. Zhao, "Share green growth: Regional evaluation of green output performance in China," Int. J. Prod. Econ., vol. 219, pp. 152-163, Jan. 2020.

[16] C. Li, D. Niu, B. Miao, and Q. Liu, "Electricity Consumption Forecast of Zhejiang Based on the Background of Electric Energy Substitution,” 2020, pp. 576-583.

[17] A. Amheka, Y. Higano, J. Tanesab, and N. Tuati, "Energy Transformation and GHG Emission Reduction Model: An empirical Strategy for Kupang City, NTT Province, Indonesia," Int. J. Renew. Energy Res., vol. 9, no. 2, pp. 1089-1096, Jun. 2019.

[18] A. Amheka and Y. Higano, "LCA of GHG Emission Based on an Input-Output Model: Estimation on a City Level in Indonesia," in 2018 International Conference on Applied Science and Technology (iCAST), 2018, pp. 343-348.

[19] M. Kamran et al., "Socio-economic acceptance for stand-alone Solar PV systems: Survey evidence from Southern Punjab, Pakistan," Int. J. Renew. Energy Res., vol. 9, no. 1, pp. 301-308, 2019.

[20] A. Amheka, "Evaluation of Economic Structure Development of Kupang City, NTT Province, Indonesia to Meet National GHG Emission Target," Reg. Sci. Inq., vol. X, no. 1, pp. 11-17, 2018.

[21] A. Li, H. Shibusawa, Y. Miyata, and M. Yamaguchi, "Assessment of Energy Technology to Abate Air Pollution Emissions in China," Stud. Reg. Sci., vol. 33, no. 1, pp. 59-73, Oct. 2002.

[22] Nusa Tenggara Timur Government, "General Regional Energy Plan of NTT Province: a draft," 2019.

[23] West Java Province Government, General Regional Energy Plan of West Java Province. .

[24] Central Java Government, General Regional Energy Plan of Central Java Province. 2018, p. 121.

[25] A. Amheka, Y. Higano, T. Mizunoya, and H. Yabar, "An overview of current household waste management in Indonesia: Development of a new integrated strategy," Int. J. Environ. Waste Manag., vol. 15, no. 1, p. 86, 2015.

[26] C. Heaps, An introduction to LEAP: Long range Energy Alternatives Planning System. 2008.

[27] Suhono, "Kajian Perencanaan Permintaan dan Penyediaan Energi Listrik di Wilayah Kabupaten Sleman menggunakan Perangkat Lunak LEAP," Gadjah Mada University, 2010.

[28] Suhono and Sarjiya, "Long-term electricity demand forecasting of Sumatera system based on electricity consumption intensity and Indonesia population projection 2010-2035," Energy Procedia, vol. 68, pp. 455-462, Apr. 2015.

[29] A. Amheka and Y. Higano, "A novelty design of GHG Emission Reduction Cost for the Province of Nusa Tenggara Timur, Indonesia: A quantitative-based scientific view," in IOP Conference Series: Earth and Environmental Science, 2018, vol. 207, no. 1, p. 012062.

[30] A. Amheka, Y. Higano, T. Mizunoya, and H. Yabar, "Comprehensive Evaluation of the Feasibility to Develop a Renewable Energy Technology System and Waste Treatment Plant in Kupang City, Indonesia based on a Kupang Input Output Table," in Procedia Environmental Sciences, 2014, vol. 20 , pp. $79-88$. 